\title{
Glucocorticoids Fail to Inhibit Arachidonic Acid Metabolism Stimulated by Hydrogen Peroxide in the Alveolar Macrophage
}

\author{
Peter H.S. Sporn, Teresa M. Murphy, and Marc Peters-Golden \\ Division of Pulmonary and Critical Care Medicine, Department of Internal Medicine, \\ University of Michigan and Veterans Administration Medical Centers, Ann Arbor
}

\begin{abstract}
We have previously demonstrated that the biologically important oxidant hydrogen peroxide $\left(\mathrm{H}_{2} \mathrm{O}_{2}\right)$ triggers release and metaboliam of arachidonic acid (AA) in the alveolar macrophage (AM). In this study, we evaluated the ability of glucocorticoids to inhiblt rat AM AA metaboliem stimulated by $\mathrm{H}_{2} \mathrm{O}_{2}$, as compared to the particulate zymosan. Methyiprednisolone and other glucocorticoids failed to significantly inhibit release of AA stimulated by $\mathrm{H}_{2} \mathrm{O}_{2}$, while markedly reducing AA release in response to zymosan. Simtlarly, methylprednisolone only woakly inhibited synthesis of thromboxane $(T x) B_{2}$ stimulated by $\mathrm{H}_{2} \mathrm{O}_{2}$, while inhibiting zymosan-induced elcosanoid syntheals to a marked dogree. On the other hand, the phosphollpase inhibitor mepacrine strongly inhibited $A A$ release and $\mathrm{TXB}_{2}$ formation stimulated by both $\mathrm{H}_{2} \mathrm{O}_{2}$ and zymosan, indicating that $\mathrm{H}_{2} \mathrm{O}_{2}$ induced AA metabolism is indeed susceptible to pharmacologic inhibition. The failure of glucocorticolds to inhiblt $A A$ metabolism stimulated by $\mathrm{H}_{2} \mathrm{O}_{2}$ in the $\mathrm{AM}$ may in part explain their inability to ameliorate oxidant-mediated lung inflammation and injury.
\end{abstract}

Key words: oxidants, zymosan, methylprednisolone, mepacrine, thromboxane, lung inflammation

\section{INTRODUCTION}

Glucocorticoid steroids are efficacious in the treatment of a variety of immune and inflammatory disorders affecting the lung and other organs. The ability of glucocorticoids to inhibit the phospholipase-catalyzed release of arachidonic acid (AA), and thereby its subsequent metabolism to bioactive eicosanoids, is believed to represent an important mechanism of their anti-inflammatory action [1-3]. The alveolar macrophage (AM), which plays a central role in regulating immune and inflammatory processes in the lung, is enriched in AA [4] and has the capacity to synthesize substantial quantities of eicosanoids via both the cyclooxygenase and the 5-lipoxygenase pathways [5-7]. In previous studies, we have examined the effects of glucocorticoids on AA metabolism in AMs challenged with the agonists zymosan and calcium ionophore A23187. Our studies demonstrated that glucocorticoids inhibit AA release and eicosanoid synthesis stimulated by the particulate zymosan in the rat AM $[8,9]$ and by the soluble stimulus A23187 in the human AM [10]. Inhibition by glucocorticoids of eicosanoid synthesis stimulated by zymosan in the human AM has also been reported [11]. Glucocorticoid inhibition of AA release and metabolism has similarly been documented in a wide variety of other cells and tissues [1-3,12-17].

Interestingly, glucocorticoids fail to ameliorate, or actually worsen, lung inflammation and injury in animals exposed to hyperoxia [18-20] or the chemical oxidant paraquat [21]. Recently, we have demonstrated that noncytolytic doses of hydrogen peroxide $\left(\mathrm{H}_{2} \mathrm{O}_{2}\right)$, a key mediator of oxidant lung injury [22-25], have the capacity to trigger the release of $\mathrm{AA}$ and its metabolism to cyclooxygenase (but not 5-lipoxygenase) products in the rat AM $[26,27]$. In the current study, we have investigated the ability of glucocorticoids to regulate rat AM AA metabolism stimulated by this biologically important oxidant. Our results indicate that, in contrast to AA metabolism stimulated by the classical agonist zymosan, glucocorticoids fail to inhibit AA release and eicosanoid synthesis triggered by $\mathrm{H}_{2} \mathrm{O}_{2}$.

Received September 25, 1989; accepted November 14, 1989.

Reprint requests: Peter H.S. Sporn, Division of Pulmonary and Critical Care Medicine, 3916 Taubman Center, University of Michigan Medical Center, Ann Arbor, MI 48109-0360. 


\section{MATERIALS AND METHODS Macrophage Isolation and Culture}

Alveolar macrophages were obtained by bronchoalveolar lavage from specific pathogen-free $126-150 \mathrm{~g}$ female Wistar rats (Charles River, Portage, MI), as previously described [26]. Two million cells suspended in medium 199 with modified Earle's salts (M199; GIBCO, Grand Island, NY) were plated in $35 \times 10 \mathrm{~mm}$ plastic culture dishes (Falcon Plastics, Oxnard, CA) and cultures at $37^{\circ} \mathrm{C}$ in a humidified atmosphere of $5 \% \mathrm{CO}_{2}$ in air. After $1 \mathrm{~h}$, non-adherent cells were removed by washing twice with Hanks' balanced salt solution (HBSS; GIBCO). The resultant adherent cell population has been found to contain $95 \%$ AMs by morphologic criteria and esterase staining [8] with viability exceeding $90 \%$. Macrophage monolayers were then cultured overnight in M199 containing $10 \%$ newborn calf serum (GIBCO), in the presence or absence of radiolabeled AA and/or glucocorticoids. Following overnight culture, these monolayers have been found to contain approximately $8.5 \mu \mathrm{g}$ DNA [8] and $100 \mu \mathrm{g}$ protein [26] per plate.

\section{Macrophage Prelabeling With [ $\left.{ }^{14} \mathrm{C}\right] \mathrm{AA}$}

Cellular lipids were prelabeled by including $0.2 \mu \mathrm{Ci}$ $\left[1-{ }^{14} \mathrm{C}\right] \mathrm{AA}$ (specific activity $54-57 \mathrm{mCi} / \mathrm{mmol}$, DupontNew England Nuclear, Boston, MA) per dish in the culture medium during overnight incubation $(\sim 16 \mathrm{~h})$, as described [27]. Macrophages incorporated 158,000 \pm $7,000 \mathrm{dpm}$ or $32 \pm 2 \%$ (mean $\pm \mathrm{SE}, \mathrm{n}=21$ ) of the added $\left[{ }^{14} \mathrm{C}\right] \mathrm{AA}$, in the absence of glucocorticoid.

\section{Pretreatment With Glucocorticolds}

Following adherence, AMs were incubated overnight $(\sim 16 \mathrm{~h})$ in the presence of varying concentrations of methylprednisolone, or with hydrocortisone $(100 \mu \mathrm{M})$, dexamethasone $(1 \mu \mathrm{M})$, or fluocinolone $(0.1 \mu \mathrm{M})$ (all glucocorticoids from Sigma Chemical, St. Louis, MO), added in dimethylsulfoxide at a final concentration of $0.5 \%$. We have previously shown that overnight incubation with hydrocortisone, dexamethasone, and fluocinolone at these concentrations, and with methylprednisolone at $\geq 1 \mu \mathrm{M}$, results in maximal glucocorticoid inhibition of zymosan-stimulated AA metabolism in the rat AM $[8,9]$. These concentrations of glucocorticoids also did not adversely affect AM viability $[8,9]$. Incubation with glucocorticoids caused dose-dependent reduction of macrophage $\left[{ }^{14} \mathrm{C}\right] \mathrm{AA}$ incorporation, with a maximal effect for methylprednisolone at $10^{-4} \mathrm{M}$, which reduced uptake to $69 \pm 2 \%(n=6)$ of the radiolabel incorporated by AMs in the absence of glucocorticoid. This effect was corrected for in all cases by expressing the quantities of radiolabeled AA and metabolites released by glucocorticoid-treated and untreated AMs as a percentage of the dpm of $\left[{ }^{14} \mathrm{C}\right] \mathrm{AA}$ incorporated with or without glucocorticoid, respectively, in each experiment.

\section{Agonist Stimulation of AA Metabolism}

After pretreatment with or without glucocorticoid, $\left[{ }^{14} \mathrm{C}\right] \mathrm{AA}$-prelabeled or unlabeled AMs were washed with HBSS and stimulated for 30 min with $\mathrm{H}_{2} \mathrm{O}_{2}$ at concentrations as indicated, or with preboiled zymosan $\mathrm{A}$ (Sigma Chemical) at $100 \mu \mathrm{g} / \mathrm{ml}$, both diluted in serumfree M199. In certain experiments (in which macrophages were not pretreated with glucocorticoid), stimulation with $\mathrm{H}_{2} \mathrm{O}_{2}$ or zymosan was carried out in the presence and absence of various concentrations of mepacrine (quinacrine; Sigma Chemical), following a 15 min pre-exposure to the drug or medium alone, respectively.

\section{Extraction, Separation, and Quantitation of $\left[{ }^{14} \mathrm{C}\right] \mathrm{AA}$}

Following agonist stimulation, cells plus media were extracted with chloroform:methanol, and free $\left[{ }^{14} \mathrm{C}\right] \mathrm{AA}$ was separated by thin layer chromatography (TLC) on Silica Gel 60 plates (E. Merck, Darmstadt, FRG) using hexane:diethyl ether:acetic acid (70:30:2, v/v/v) and quantitated by scintillation counting, as described [26].

\section{Extraction, Separation, and Quantitation of Eicosanoids}

Following stimulation, media from both labeled and unlabeled cultures were extracted using Sep-pak $C_{18}$ cartridges (Waters Associates, Milford, MA), and the extracts were dried under $\mathrm{N}_{2}$ [27].

For separation of radiolabeled metabolites produced by $\left[{ }^{14} \mathrm{C}\right] \mathrm{AA}$ prelabeled AMs, extracts of pooled media from triplicate cultures were dissolved in acetonitrile: water:trifluoroacetic acid (33:67:0.1, v/v/v) and subjected to reverse-phase high performance liquid chromatography (HPLC) over a Waters $5 \mu \mathrm{m}$ Bondapak column $(30 \times 0.4 \mathrm{~cm})$ eluted with acetonitrile:water:trifluoroacetic acid at $1 \mathrm{ml} / \mathrm{min}$, as previously described [9]. Using this system, cyclooxygenase metabolites are eluted during an initial isocratic phase (33:67:0.1, v/v/v), followed by lipoxygenase metabolites and free AA, which elute during a stepwise gradient increase of acetonitrile to 100:0:0.1 (v/v/v). Radiolabeled AA and its metabolites were identified on the basis of retention times corresponding to those of authentic standards as determined by UV absorbance. Authentic prostaglandin (PG) and thromboxane $(\mathrm{Tx}) \mathrm{B}_{2}$ standards were generous gifts of Dr. J. Pike (Upjohn Co., Kalamazoo, MI), and lipoxygenase standards of Dr. J. Rokach (Merck Frosst, Inc., Pointe Claire-Dorval, Quebec, Canada). Authentic 12hydroxy-5,8,10-heptadecatrienoic acid (HHT) was ob- 


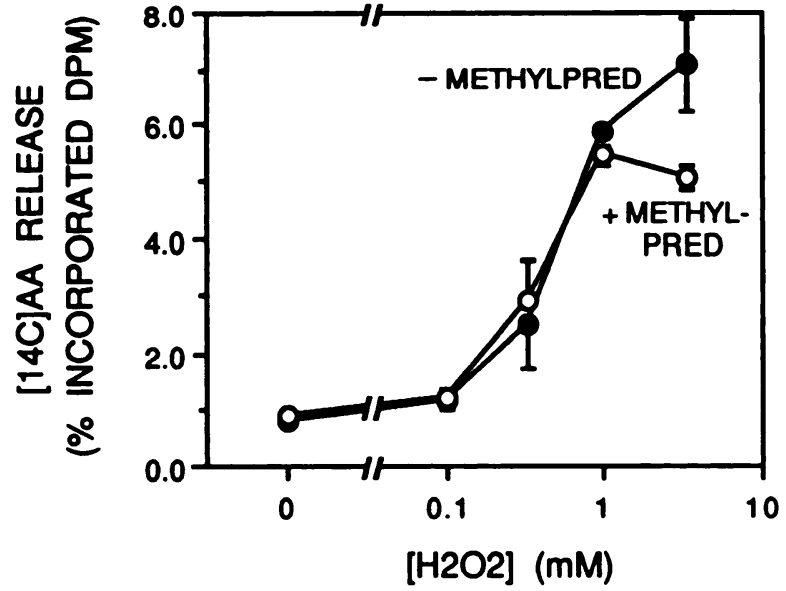

Fig. 1. Effect of $1 \mu \mathrm{M}$ methylprednisolone on AA release by alveolar macrophages stimulated with various doses of $\mathrm{H}_{2} \mathrm{O}_{2}$. After incubation for $\sim 16 \mathrm{~h}$ in the absence or presence of $1 \mu \mathrm{M}$ methylprednisolone, monolayers of $\left[{ }^{14} \mathrm{C}\right] \mathrm{AA}$-prelabeled AMs were washed, media containing the Indicated concentrations of $\mathrm{H}_{2} \mathrm{O}_{2}$ were added, and cultures were incubated for $30 \mathrm{~min}$. Media plus cells were then extracted, and free $\left[{ }^{14} \mathrm{C}\right] A$ A was separated by TLC and quantitated by scintillation counting. The results represent means I SE of data from 3 individual experiments, each performed in duplicate.

tained from Cayman Chemical Co. (Ann Arbor, MI), and the AA standard from Nu-Chek Prep (Elysian, MN). Eluate fractions of $1 \mathrm{ml}$ were collected, and radioactivity quantitated in $6 \mathrm{ml}$ of scintillant.

Thromboxane $A_{2}$ produced by unlabeled macrophages was quantitated as the stable metabolite $\mathrm{TxB}_{2}$ by radioimmunoassay [26]. Dried Sep-pak extracts were redissolved in $1 \mathrm{ml}$ of phosphate-buffered saline containing $0.1 \%$ gelatin, and $0.1 \mathrm{ml}$ aliquots were assayed in duplicate. Results were corrected for recovery of each sample during extraction.

\section{$\mathrm{H}_{2} \mathrm{O}_{2}$ Assay}

$\mathrm{H}_{2} \mathrm{O}_{2}$ was measured by the homovanillic acid-horseradish peroxidase assay of Ruch et al. [28]. The $t_{1 / 2}$ of $\mathrm{H}_{2} \mathrm{O}_{2}$ was determined from the linear regression equation for a plot of $\log \left[\mathrm{H}_{2} \mathrm{O}_{2}\right]$ vs. time.

\section{Data Analysis}

Throughout the study, duplicate culture plates were utilized for each experimental condition and the resulting values averaged to yield a single data point (except in experiments where HPLC was employed, in which case material from triplicate cultures was combined for a single analysis). All data for which $n \geq 3$ are expressed as the mean $\pm \mathrm{SE}$. The significance of differences between group means was assessed by paired or unpaired Student's t-tests, or by one-way analysis of variance and the

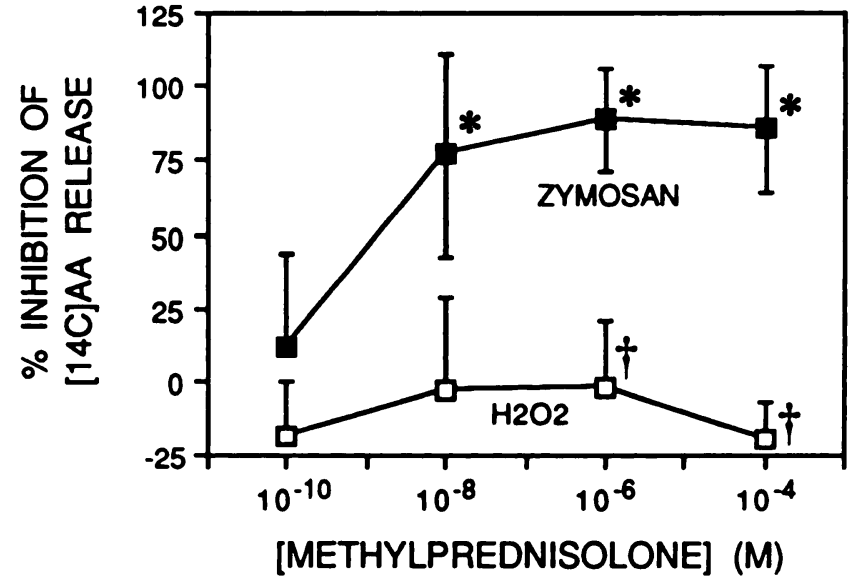

Fig. 2. Effect of methylprednisolone concentration on AA release by alveolar macrophages stimulated with $\mathrm{H}_{2} \mathrm{O}_{2}$ and zymosan. After incubation for $\sim 16 \mathrm{~h}$ in the absence or presence of the indicated concentrations of methylprednisolone, monolayers of [ $\left.{ }^{14} \mathrm{C}\right] A A$-prelabeled AMs were stimulated with $1 \mathrm{mM} \mathrm{H} \mathrm{H}_{2} \mathrm{O}_{2}$ or $100 \mu \mathrm{g} / \mathrm{ml}$ zymosan for $30 \mathrm{~min}$. Free [ $\left.{ }^{14} \mathrm{C}\right] A$ A was then separated and quantitated as described in the legend to Figure 1. The results represent means \pm SE of data from 3 or 4 individual experiments at each methylprednisolone concentration. "P $<0.005$ v8. zymosan without methylprednisolone, by analysis of variance and the Newman-Keuls multiple range test. $+\boldsymbol{P}<0.02$ vs. zymosan at the corresponding methylprednisolone concentration, by paired t-test. $\mathrm{H}_{2} \mathrm{O}_{2}$-induced $\left[{ }^{14} \mathrm{C}\right] \mathrm{AA}$ released was not significantly affected by mothylprednisolone at any concentration (P $>0.05$ by analysis of variance and the Newman-Keuls multiple range teat).

Newman-Keuls multiple range test, as appropriate [29]. In all cases, $P<0.05$ was considered significant.

\section{RESULTS \\ Effect of Methylprednisolone on $\mathrm{H}_{2} \mathrm{O}_{2}$ - and Zymosan-Induced AA Metabolism}

In our previous study [9], methylprednisolone maximally inhibited zymosan-induced rat $\mathrm{AM}$ eicosanoid synthesis at a concentration of $1 \mu \mathrm{M}$, by $\sim 80 \%$. We therefore examined the effect of methylprednisolone at 1 $\mu \mathrm{M}$ on the release of $\left[{ }^{14} \mathrm{C}\right] \mathrm{AA}$ stimulated by $\mathrm{H}_{2} \mathrm{O}_{2}$ in prelabeled AMs. Figure 1 shows that at this concentration methylprednisolone did not inhibit the dose-dependent release of free $\left[{ }^{14} \mathrm{C}\right] A A$ stimulated by $\mathrm{H}_{2} \mathrm{O}_{2}$. Indeed, as illustrated in Figure 2, methylprednisolone from $10^{-10}$ to $10^{-4} \mathrm{M}$ failed to inhibit $\left[{ }^{14} \mathrm{C}\right] \mathrm{AA}$ release induced by $1 \mathrm{mM} \mathrm{H}_{2} \mathrm{O}_{2}$, in contrast to its ability to markedly inhibit $\left[{ }^{14} \mathrm{C}\right] \mathrm{AA}$ release stimulated by zymosan. It was similarly demonstrated that the additional glucocorticoids hydrocortisone $(100 \mu \mathrm{M})$, dexamethasone (1 $\mu \mathrm{M})$, and fluocinolone $(0.1 \mu \mathrm{M})$ failed to inhibit or only slightly inhibited $\left[{ }^{14} \mathrm{C}\right] \mathrm{AA}$ release triggered by $\mathrm{H}_{2} \mathrm{O}_{2}$, 
TABLE 1. Effect of Hydrocortisone $(100 \mu \mathrm{M})$, Dexamethasone $(1 \mathrm{\mu M})$, and Fluocinolone $(0.1 \mathrm{\mu M})$ on Release of [ $\left.{ }^{14} \mathrm{C}\right] \mathrm{AA}$ by Alveolar Macrophages Stimulated With $\mathrm{H}_{2} \mathrm{O}_{2}$ and With Zymosan"

$\%$ inhibition of $\left[{ }^{14} \mathrm{C}\right]$ AA release

Agonist Hydrocortisone Dexamethasone Fluocinolone

$\mathrm{H}_{2} \mathrm{O}_{2}(1 \mathrm{mM}) \quad 14 \quad 20 \quad 3$

Zymosan $(100 \mu \mathrm{g} / \mathrm{ml}) \quad 66 \quad 55 \quad 50$

ata represent the average of duplicates from one experiment.

while, as previously reported [8], strongly inhibiting that stimulated by zymosan (Table 1 ).

The effect of methylprednisolone on eicosanoid synthesis by $\left[{ }^{14} \mathrm{C}\right] \mathrm{AA}$-labeled AMs was analyzed using reverse-phase HPLC. Figure $3 \mathrm{~A}$ shows that $1 \mathrm{mM} \mathrm{H}_{2} \mathrm{O}_{2}$ triggers synthesis of the cyclooxygenase metabolites $\mathrm{TxB}_{2}$ and HHT, as well as release of a large amount of unmetabolized free $\left[{ }^{14} \mathrm{C}\right] \mathrm{AA}$, although it does not stimulate 5-lipoxygenase metabolism, as we have previously demonstrated [26,27]. Methylprednisolone $(1 \mu \mathrm{M})$ had only a minor inhibitory effect on $\mathrm{H}_{2} \mathrm{O}_{2}$-induced synthesis of these cyclooxygenase metabolites and release of free $\left[{ }^{14} \mathrm{C}\right] \mathrm{AA}$ (Fig. 3B), such that the total release of radiolabeled AA plus metabolites (calculated as the sum of the radioactivity in all HPLC fractions) was reduced by the glucocorticoid by only $16.5 \%$. As shown in Figure $3 \mathrm{C}$, the profile of metabolites synthesized in response to zymosan differs from that stimulated by $\mathrm{H}_{2} \mathrm{O}_{2}$, and includes substantial amounts of the 5-lipoxygenase metabolites $\mathrm{LTB}_{4}, \mathrm{LTC}_{4}$, and 5-HETE, in addition to cyclooxygenase metabolites and a lesser amount of free $\left[{ }^{14} \mathrm{C}\right] \mathrm{AA}$. Importantly, synthesis of all eicosanoids and release of free AA stimulated by zymosan were markedly inhibited by methylprednisolone (Fig. 3D), such that total radiolabeled AA plus metabolites were reduced by $76.2 \%$. Of note, the total release of radiolabeled AA plus metabolites stimulated by $\mathrm{H}_{2} \mathrm{O}_{2}(4.17 \%$ of incorporated dpm) was very similar to that stimulated by zymosan (4.28\% of incorporated dpm), indicating that the difference in inhibition by methylprednisolone of $\mathrm{H}_{2} \mathrm{O}_{2}$ - and zymosan-induced AA metabolism was not the result of differing potencies of the two agonists as stimuli for the liberation of esterified AA.

We also used radioimmunoassay to measure release of $\mathrm{TxB}_{2}$ by unlabeled AMs stimulated with $\mathrm{H}_{2} \mathrm{O}_{2}$ or zymosan. In these experiments, methylprednisolone $(1 \mu \mathrm{M})$ only weakly inhibited synthesis of immunoreactive $\mathrm{TxB}_{2}$ stimulated by $\mathrm{H}_{2} \mathrm{O}_{2}$, while strongly inhibiting $\mathrm{TxB}_{2}$ formation induced by zymosan (Table 2). Thus, results obtained by radioimmunoassay from unlabeled cultures corroborated those obtained using $\left[{ }^{14} \mathrm{C}\right] \mathrm{AA}$-prelabeled cells and analysis by HPLC.

\section{Effect of Mepacrine on $\mathrm{H}_{2} \mathrm{O}_{2}$ - and Zymosan-Induced AA Metabolism}

We also examined the effects of mepacrine [30], a phospholipase inhibitor unrelated to glucocorticoids, on $\mathrm{H}_{2} \mathrm{O}_{2}$ - and zymosan-induced AA metabolism. As shown in Figure 4, mepacrine markedly inhibited $\left[{ }^{14} \mathrm{C}\right] \mathrm{AA}$ release stimulated by both $\mathrm{H}_{2} \mathrm{O}_{2}$ and zymosan, in dosedependent fashion. Also, $1 \mathrm{mM}$ mepacrine almost completely blocked both $\mathrm{H}_{2} \mathrm{O}_{2}-$ and zymosan-induced immunoreactive $\mathrm{TxB}_{2}$ synthesis by unlabeled macrophages (Table 3). To determine whether inhibition of $\mathrm{H}_{2} \mathrm{O}_{2}$-stimulated AA metabolism by mepacrine might merely be the result of the inhibitor scavenging $\mathrm{H}_{2} \mathrm{O}_{2}$, we measured the rate of consumption of $1 \mathrm{mM} \mathrm{H}_{2} \mathrm{O}_{2}$ added to macrophage cultures in the absence and presence of mepacrine at $1 \mathrm{mM}$ (the highest concentration used). $\mathrm{H}_{2} \mathrm{O}_{2}$ was consumed at identical rates in AM cultures with $\left(\mathrm{t}_{1 / 2}=13.8 \pm 1.8 \mathrm{~min}, \mathrm{n}=3\right)$ and without mepacrine $\left(t_{1 / 2}=14.4 \pm 2.1 \mathrm{~min}, \mathrm{n}=3\right)$, indicating that mepacrine did not inhibit $\mathrm{H}_{2} \mathrm{O}_{2}$-induced $\mathrm{AA}$ metabolism by scavenging $\mathrm{H}_{2} \mathrm{O}_{2}$. Thus, mepacrine indeed differed from methylprednisolone in its ability to actually inhibit release of $\mathrm{AA}$ and cyclooxygenase metabolism stimulated by $\mathrm{H}_{2} \mathrm{O}_{2}$.

\section{DISCUSSION}

In this report, we have demonstrated that while methylprednisolone and other glucocorticoids potently inhibited alveolar macrophage AA release and eicosanoid formation stimulated by the particulate zymosan, they failed to inhibit AA metabolism triggered by the oxidant $\mathrm{H}_{2} \mathrm{O}_{2}$. These findings indicate that inhibition of AA metabolism by glucocorticoids represents an agonist-specific regulatory interaction. On the other hand, the phospholipase inhibitor mepacrine, which acts by a mechanism unrelated to that of glucocorticoids (involving formation of mepacrine-phospholipid complexes, as well as possible direct interaction with phospholipase enzyme [30]) blocked AA metabolism stimulated not only by zymosan, but by $\mathrm{H}_{2} \mathrm{O}_{2}$ as well. Thus, $\mathrm{H}_{2} \mathrm{O}_{2}$-induced AA metabolism is indeed susceptible to pharmacologic inhibition, although not by glucocorticoids.

Glucocorticoids have been proposed to exert their inhibitory effect on AA metabolism by inducing synthesis of phospholipase inhibitory proteins $[16,31]$, termed lipocortins [32]. Lipocortins have been shown to inhibit phospholipase $A_{2}$ in cell-free assays by binding its phospholipid substrate, rather than by directly interacting with the enzyme itself $[33,34]$. Although purified mouse lung lipocortins [35] and recombinant human lipocortin $[36,37]$ have been shown to inhibit AA metabolism in several tissues (including the AM [35]), lipocortin's role 


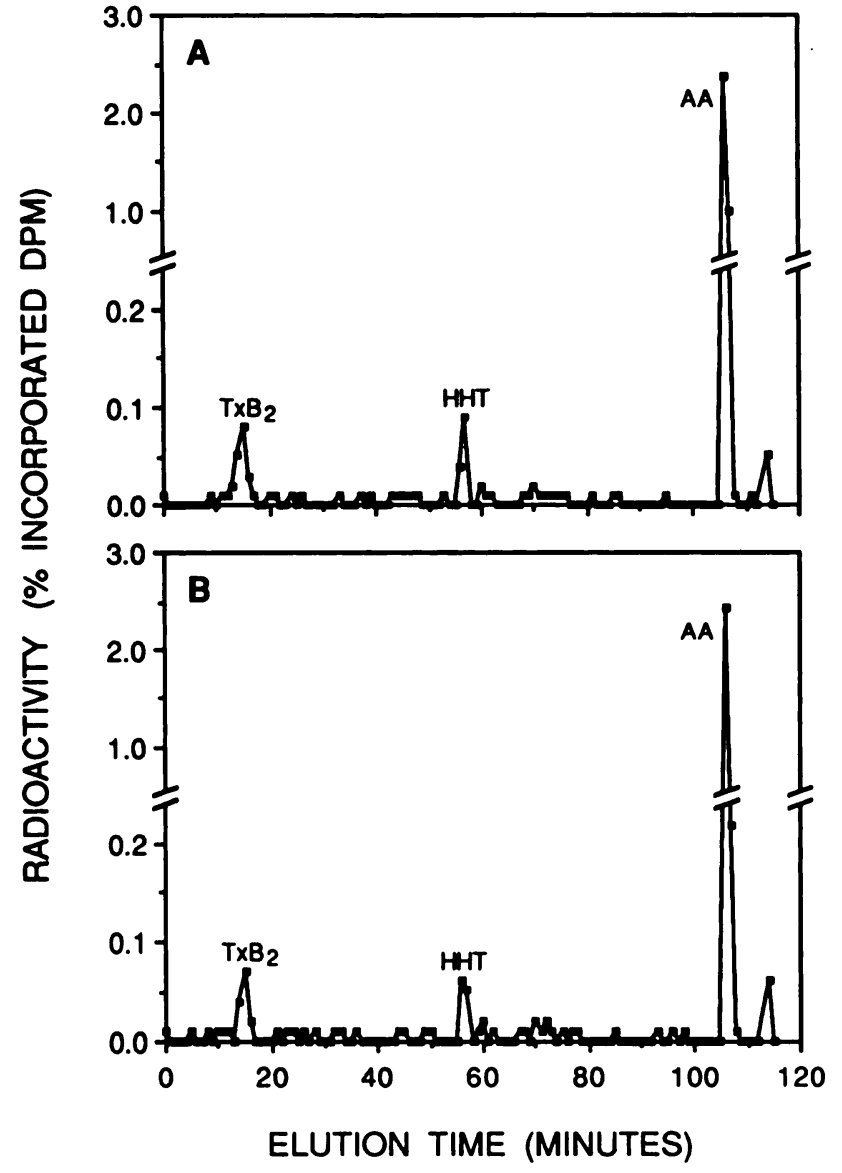

Fig. 3. HPLC analysis of effect of methylprednisolone on $\mathrm{H}_{2} \mathrm{O}_{2}$ and zymosan-induced elcosanold formation and $A A$ release by alveolar macrophages. After incubation for $\sim 16 \mathrm{~h}$ in the absence or presence of $1 \mu \mathrm{M}$ methylprednisolone, monolayers of [ $\left.{ }^{14} \mathrm{C}\right]$ AA-prelabeled AMs were stimulated with $1 \mathrm{mM} \mathrm{H}_{2} \mathrm{O}_{2}$ or 100 $\mu \mathrm{g} / \mathrm{ml}$ zymosan for $\mathbf{3 0} \mathrm{min}$. Pooled medla from triplicate cultures were extracted using Sep-pak $C_{18}$ cartridges, and subjected to reverse-phase HPLC as described in Materials and

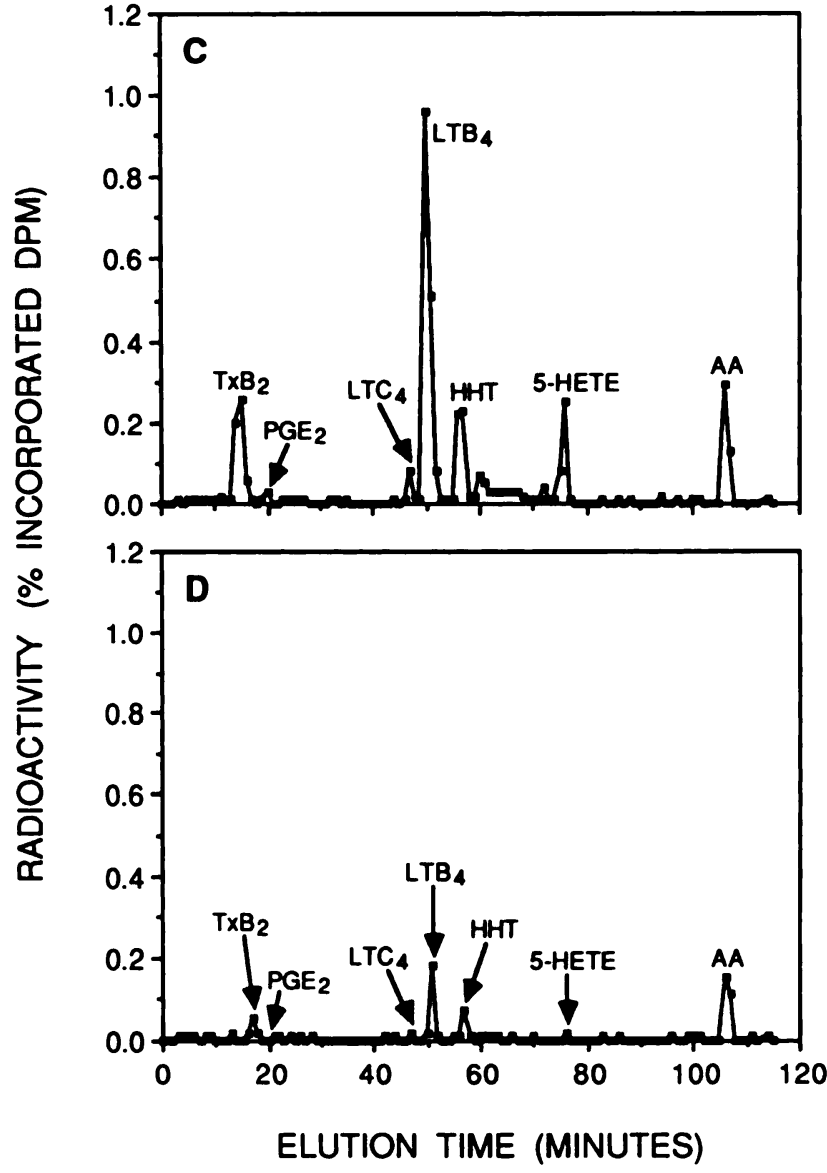

Methods. Radioactivity in 1 min eluate fractions was quantitated, and expressed as a percentage of the total radioactivity incorporated per culture plate prior to stimulation. Radioactivity peaks corresponding to retention times of authentic standards are indicated by labels. $\mathrm{A}: \mathrm{H}_{2} \mathrm{O}_{2} \cdot \mathrm{B}: \mathrm{H}_{2} \mathrm{O}_{2}$ after pretreatment with methylprednisolone. C: Zymosan. D: Zymosan after pretreatment with methylprednisolone.

TABLE 2. Effect of Methylprednisolone $(1 \mu \mathrm{M})$ on Synthesis of Immunoreactive $\mathrm{TXB}_{2}$ by Alveolar Macrophages Stimulated Whth $\mathrm{H}_{2} \mathrm{O}_{2}$ and With Zymosan

\begin{tabular}{|c|c|c|c|c|}
\hline \multirow[b]{2}{*}{ Agonist } & \multirow[b]{2}{*}{ (n) } & \multicolumn{2}{|c|}{$\mathrm{TxB}_{2}$ synthesis (pg/plate) } & \multirow[b]{2}{*}{$\%$ inhibition } \\
\hline & & $\begin{array}{l}\text { Without } \\
\text { methylpred- } \\
\text { nisolone }\end{array}$ & $\begin{array}{c}\text { With } \\
\text { methylpred- } \\
\text { nisolone }\end{array}$ & \\
\hline None & (10) & $310 \pm 50$ & $185 \pm 24$ & \\
\hline $\mathrm{H}_{2} \mathrm{O}_{2}(1 \mathrm{mM})$ & (6) & $1,988 \pm 435$ & $1,402 \pm 208^{*}$ & $22 \pm 7^{* * *}$ \\
\hline Zymosan $(100 \mu \mathrm{g} / \mathrm{ml})$ & (8) & $2,188 \pm 373$ & $548 \pm 86^{* *}$ & $82 \pm 4$ \\
\hline
\end{tabular}

$* P$ not significant $(>0.05)$ vs. $\mathrm{H}_{2} \mathrm{O}_{2}$ without methylprednisolone, by paired t-test.

$* * P<0.0025$ vs. zymosan without methylprednisolone, by paired t-test.

$* * * P<0.0001$ vs. zymosan, by unpaired t-test.

as the actual endogenous second messenger responsible for glucocorticoid inhibition of AA metabolism has recently been challenged [38-40], raising the possibility that another glucocorticoid-induced protein(s) may serve this function physiologically.

Based on this model of glucocorticoids' inhibitory ac- 


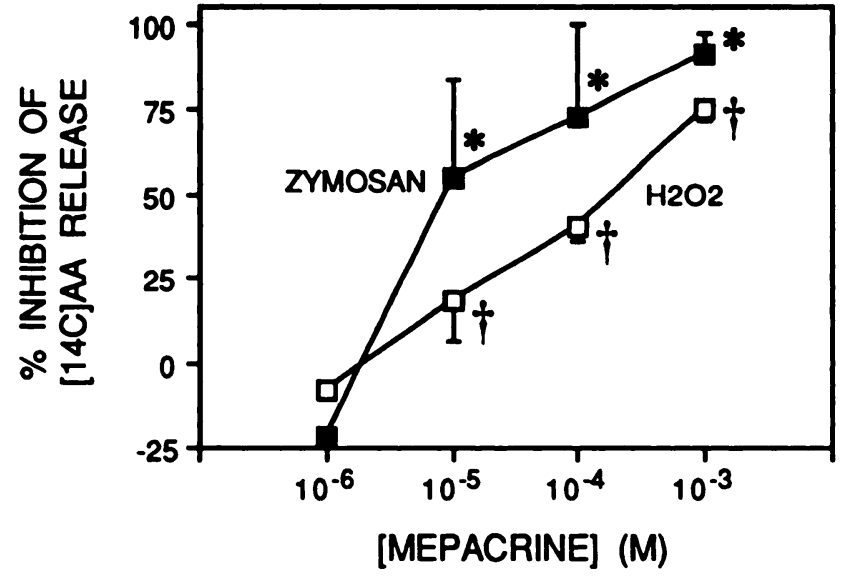

Fig. 4. Effect of mepacrine on AA release by alveolar macrophages stimulated with $\mathrm{H}_{2} \mathrm{O}_{2}$ and zymosan. Alveolar macrophages prolaboled with [ [4C]AA were stimulated with $1 \mathrm{mM}$ $\mathrm{H}_{2} \mathrm{O}_{2}$ or $100 \mu \mathrm{g} / \mathrm{ml}$ zymosan for $30 \mathrm{~min}$ in the presence and absence of the indicated concentrations of mepacrine, following a $15 \mathrm{~min}$ pre-exposure to the drug or medlum alone, respectively. Free $\left[{ }^{14} \mathrm{C}\right] A \mathrm{~A}$ was then separated and quantitated as doscribed in the legend to Figure 1. The results represent means \pm SE of data from 3 to 6 individual experiments, each performed in duplicate (except for [mepacrine] $=10^{-6} \mathrm{M}$, for which the means of duplicates from a single experiment are shown). "P $<0.05$ v8. zymosan without mepserine, by analysis of variance and the Newman-Keuls multiple range teat. $+P<0.025$ v8. $\mathrm{H}_{2} \mathrm{O}_{2}$ without mepacrine, by analysis of variance and the NewmanKeuls multiple range test.

TABLE 3. Effect of Mepacrine (1 $\mathrm{mM}$ ) on Synthesis of Immunoreactive $\mathrm{TxB}_{2}$ by Alveolar Macrophages Stimulated With $\mathrm{H}_{2} \mathrm{O}_{2}$ and With Zymosan

\begin{tabular}{llccc}
\hline & & \multicolumn{2}{c}{$\mathrm{TxB}_{2}$ synthesis (pg/plate) } & \\
\cline { 2 - 4 } & & Without & With & \\
Agonist & (n) & mepacrine & mepacrine & $\%$ inhibition \\
\hline None & $(4)$ & $138 \pm 19$ & $14 \pm 12$ & \\
$\mathrm{H}_{2} \mathrm{O}_{2}(1 \mathrm{mM})$ & $(3)$ & $821 \pm 34$ & $116 \pm 27^{*}$ & $83 \pm 4$ \\
Zymosan $(100 \mu \mathrm{g} / \mathrm{ml})$ & $(4)$ & $1,452 \pm 324$ & $51 \pm 35^{* *}$ & $95 \pm 5$ \\
\hline
\end{tabular}

*P $<0.0025$ vs. $\mathrm{H}_{2} \mathrm{O}_{2}$ without mepacrine, by paired $\mathrm{t}$-test.

**P$<0.05$ vs. zymosan without mepacrine, by paired $t$-test.

tion, a number of potential explanations for their inability to inhibit AA metabolism induced by $\mathrm{H}_{2} \mathrm{O}_{2}$ may be proposed. 1) $\mathrm{H}_{2} \mathrm{O}_{2}$ might oxidatively inactivate lipocortin, or some other glucocorticoid-induced second messenger protein. 2) Peroxidation of membrane lipids by $\mathrm{H}_{2} \mathrm{O}_{2}$ might alter lipocortin binding to phospholipids, and thereby impair the ability of the putative inhibitor protein to block phospholipase action. 3) Rather than stimulating AA release via phospholipase $\mathrm{A}_{2}, \mathrm{H}_{2} \mathrm{O}_{2}$ might cause AA to be released via a pathway involving phospholipase $C$, which is much less sensitive than phospholipase $A_{2}$ to glucocorticoid inhibition [41]. 4) Since macrophages exhibit very high rates of fatty acyl turn- over in their phospholipids [42], the increases in free AA and metabolites generated in response to $\mathrm{H}_{2} \mathrm{O}_{2}$ may in large part result from oxidative inhibition of reacylation of deacylated AA back to phospholipids, rather than from activation of phospholipase(s), the enzymatic step which is the putative locus of glucocorticoid inhibition. Further investigation will be required to determine the importance of these or other possible mechanisms which may be responsible for the failure of glucocorticoids to inhibit AA metabolism stimulated by $\mathrm{H}_{2} \mathrm{O}_{2}$.

Differences in the susceptibility of AA metabolism triggered by various stimuli to inhibition by glucocorticoids may be an important determinant of the degree to which certain experimental or clinical disease processes do or do not respond to glucocorticoid pharmacotherapy. In particular, the failure of glucocorticoids to inhibit AA metabolism stimulated by $\mathrm{H}_{2} \mathrm{O}_{2}$ may in part explain their inability to ameliorate oxidant-mediated lung injury in animals [18-21], or to improve survival in the human adult respiratory distress syndrome $[43,44]$, in which oxidants appear to also play an important role $[45,46]$.

\section{ACKNOWLEDGMENTS}

This work was supported by funds from the National Institutes of Health (HL-01638), the Research Service of the Veterans Administration, the American Lung Association, the Rackham Faculty Grant of the University of Michigan, and the Michigan-Memorial Phoenix Project. Peter H.S. Sporn is a recipient of an Edward Livingston Trudeau Scholar Award from the American Lung Association and a Career Development Award from the Veterans Administration.

\section{REFERENCES}

1. Lewis, G.P., and Piper, P.J. Inhibition of release of prostaglandins as an explanation of some of the actions of anti-inflammatory corticosteroids. Nature 254,308, 1975.

2. Hong, S.L., and Levine, L. Inhibition of arachidonic acid release from cells as the biochemical action of anti-inflammatory corticosteroids. Proc. Natl. Acad. Sci. U.S.A. 73,1730, 1976.

3. Hammerstrom, S., Hamberg, M., Duell, E.A., Stawiski, Z.A., Anderson, T.F., and Voorhies, J.J. Glucocorticoid in inflammatory proliferative skin disease reduces arachidonic and hydroxyeicosatetraenoic acids. Science 197,994, 1977.

4. Mason, R.J., Stossel, T.P., and Vaughn, M. Lipids of alveolar macrophages, polymorphonuclear leukocytes, and their phagocytic vesicles. J. Clin. Invest. 51,2399, 1972.

5. Laviolette, M., Chang, J., and Newcombe, D.S. Human alveolar macrophages: A lesion in arachidonic acid metabolism in cigarette smokers. Am. Rev. Respir. Dis. 124,397, 1981.

6. Rouzer, C.A., Scott, W.A., Hamill, A.L., and Cohn, Z.A. Synthesis of leukotriene $C$ and other arachidonic acid metabolites by mouse pulmonary macrophages. J. Exp. Med. 155,720, 1982.

7. Fels, A.O.S., Pawlowski, N.A., Cramer, E.B., King, T.K.C., Cohn, Z.A., and Scott, W.A. Human alveolar macrophages pro- 
duce leukotriene $B_{4}$. Proc. Natl. Acad. Sci. U.S.A. 79,7866, 1982.

8. Peters-Golden, M., Bathon, J. Flores, R., Hirata, F., and Newcombe, D.S., Glucocorticoid inhibition of zymosan-induced arachidonic acid release by rat alveolar macrophages. Am. Rev. Respir. Dis. 130,803, 1984.

9. Peters-Golden, M., and Thebert, P. Inhibition by methylprednisolone of zymosan-induced leukotriene synthesis in alveolar macrophages. Am. Rev. Respir. Dis. 135,1020, 1987.

10. Balter, M.S., Eschenbacher, W.L., and Peters-Golden, M. Arachidonic acid metabolism in cultured alveolar macrophages from normal, atopic, and asthmatic subjects. Am. Rev. Respir. Dis. 138,1134, 1988.

11. Fuller, R.W., Kelsey, C.R., Cole, P.J., Dollery, C.T., and MacDermot, J. Dexamethasone inhibits the production of thromboxane $B_{2}$ and leukotriene $B_{4}$ by human alveolar and peritoneal macrophages in culture. Clin. Sci. 67,653, 1984.

12. Kantrowitz, F., Robinson, D.R., McGuire, M.B., and Levine, L. Corticosteroids inhibit prostaglandin production by rheumatoid synovia. nature $258,737,1975$.

13. Chandrabose, K.A., Lapetina, E.G., Schmitges, C.J., Siegel, M.I., and Cuatrecasas, P. Action of corticosteroids in regulation of prostaglandin biosynthesis in cultured fibroblasts. Proc. Natl. Acad. Sci. U.S.A. 75,214, 1978.

14. Blackwell, G.J., Flower, R.J., Nijkamp, F.P., and Vane, J.R. Phospholipase $A_{2}$ activity of guinea-pig isolated perfused lungs: Stimulation and inhibition by anti-inflammatory steroids. Br. J. Pharmacol. 62,79, 1978.

15. Russo-Marie, F., Paing, M., and Duval, D. Involvement of glucocorticoid receptors in steroid-induced inhibition of prostaglandin secretion. J. Biol Chem. 254,8498, 1979.

16. Hirata, F., Schiffman, E., Venkatasubramanian, K., Salomon, D., and Axelrod, J. A phospholipase $A_{2}$ inhibitory protein in rabbit neutrophils induced by glucocorticoids. Proc. Natl. Acad. Sci. U.S.A. 77,2533, 1980.

17. Mitchell, M.D., Carr, B.R., Mason, J.I., and Simpson, E.R. Prostaglandin biosynthesis in the human fetal adrenal gland: Regulation by glucocorticosteroids. Proc. Natl. Acad. Sci. U.S.A. 79,7547, 1982.

18. Yam, J., and Roberts, R.J. Pharmacological alteration of oxygeninduced lung toxicity. Toxicol. Appl. Pharmacol. 47,367, 1979.

19. Gross, N.J., and Smith, D.M. Methylprednisolone increases the toxicity of oxygen in adult mice: Mechanical and biochemical effects on the surfactant system. Am. Rev. Respir. Dis. 129,805, 1984.

20. Koizumi, M., Frank, L., and Massaro, D. Oxygen toxicity in rats: Varied effect of dexamethasone treatment depending on duration of hyperoxia. Am. Rev. Respir. Dis. 131,907, 1985.

21. Seidenfeld, J.J. Steroid pretreatment does not prevent paraquat pneumonitis in rabbits. Am. J. Med. Sci. 289,51, 1985.

22. Johnson, K.J., Fantone, J.C., III, Kaplan, J., and Ward, P.A. In vivo damage of rat lungs by oxygen metabolites. J. Clin. Invest. $67,983,1981$.

23. Martin, W.J., II, Gadek, J.E., Hunninghake, G.W., and Crystal, R.G. Oxidant injury of lung parenchymal cells. J. Clin. Invest. $68,1277,1981$

24. Tate, R.M., Vanbenthuysen, K.M., Shasby, D.M., McMurtry, I.F., and Repine, J.E. Oxygen-radical-mediated permeability edema and vasoconstriction in isolated perfused rabbit lungs. Am. Rev. Respir. Dis. 126,802, 1982.

25. Martin, W.J., II. Neutrophils kill pulmonary endothelial cells by a hydrogen-peroxide-dependent pathway: An in vitro model of neutrophil-mediated lung injury. Am. Rev. Respir. Dis. 130,209, 1984.
26. Sporn, P.H.S., Peters-Golden, M., and Simon, R.H. Hydrogenperoxide-induced arachidonic acid metabolism in the rat alveolar macrophage. Am. Rev. Respir. Dis. 137,49, 1988.

27. Sporn, P.H.S., and Peters-Golden, M. Hydrogen peroxide inhibits alveolar macrophage 5-lipoxygenase metabolism in association with depletion of ATP. J. Biol Chem. 263,14776, 1988.

28. Ruch, W., Cooper, P.H., and Baggiolini, M. Assay of $\mathrm{H}_{2} \mathrm{O}_{2}$ production by macrophages and neutrophils with homovanillic acid and horse-radish peroxidase. J. Immunol. Methods 63,347, 1983.

29. Snedecor, G.W., and Cochran, W.G. Statistical Methods (6th Ed.). Ames: Iowa State University Press, pp. 91-119, 258-298, 1967.

30. Dise, C.A., Burch, J.W., and Goodman, D.B.P. Direct interaction of mepacrine with erythrocyte and platelet membrane phospholipid. J. Biol. Chem. 257,4701, 1982.

31. Blackwell, G.J., Carnuccio, R., Di Rosa, M., Flower, R.J., Parente, L., and Persico, P. Macrocortin: A polypeptide causing the anti-phospholipase effect of glucocorticoids. Nature 287,147, 1980.

32. Di Rosa, M., Flower, R.J., Hirata, F., Parente, L., and RussoMarie, F. Nomenclature announcement: Anti-phospholipase proteins. Prostaglandins 28,441, 1984.

33. Davidson, F.F., Dennis, E.A., Powell, M., and Glenney, J.R., Jr. Inhibition of phospholipase $A_{2}$ by "lipocortins" and calpactins: An effect of binding to substrate phospholipids. J. Biol. Chem. 262,1698, 1987.

34. Haigler, H.T., Schlaepfer, D.D., and Burgess, W.H. Characterization of lipocortin I and an immunologically unrelated $33-\mathrm{kDa}$ protein as epidermal growth factor receptor/kinase substrates and phospholipase $A_{2}$ inhibitors. J. Biol. Chem. 262,6921, 1987.

35. Errasfa, M., Bachelet, M., and Russo-Marie, F. Inhibition of phospholipase $A_{2}$ activity of guinea-pig alveolar macrophages by lipocortin-like proteins purified from mice lung. Biochem. Biophys. Res. Commun. 153,1267, 1988.

36. Cirino, G., Flower, R.J., Browning, J.L., Sinclair, L.K., and Pepinsky, R.B. Recombinant human lipocortin 1 inhibits thromboxane release from guinea-pig isolated perfused lung. Nature $328,270,1987$.

37. Cirino, G., and Flower, R.J. Human recombinant lipocortin 1 inhibits prostacyclin production by human umbilical artery in vitro. Prostaglandins 34,59, 1987.

38. Northrup, J.K., Valentine-Braun, K.A., Johnson, L.K., Severson, D.L., and Hollenberg, M.D. Evaluation of the anti-inflammatory and phospholipase-inhibitory activity of calpactin II/lipocortin I. J. Clin. Invest. 82,1347, 1988.

39. Hullin, F., Raynal, P. Ragab-Thomas, J.M.F., Fauvel, J., and Chap, H. Effect of dexamethasone on prostaglandin synthesis and on lipocortin status in human endothelial cells: Inhibition of prostaglandin $\mathrm{I}_{2}$ synthesis occurring without alteration of arachidonic acid liberation and of lipocortin synthesis. J. Biol Chem. 264,3506, 1989.

40. Bienkowski, M.J., Petro, M.A., and Robinson, L.J. Inhibition of thromboxane A synthesis in U937 cells by glucocorticoids: Lack of evidence for lipocortin 1 as the second messenger. J. Biol Chem. 264,6536, 1989.

41. DeGeorge, J.J., Ousley, A.H., McCarthy, K.D., Morell, P., and Lapetina, E.G. Glucocorticoids inhibit the liberation of arachidonate but not the rapid production of phospholipase $\mathrm{C}$-dependent metabolites in acetylcholine-stimulated C62B glioma cells. J. Biol. Chem. 262,9979, 1987.

42. Kuwae, T., Schmid, P.C., and Schmid, H.H.O. Assessment of phospholipid deacylation-reacylation cycles by a stable isotope technique. Biochem. Biophys. Res. Commun. 142,86, 1987. 


\section{Sporn et al.}

43. Bernard, G.R., Luce, J.M., Sprung, C.L., Rinaldo, J.E., Tate, R.M., Sibbald, W.J., Kariman, K., Higgins, S., Bradley, R., Metz, C.A., Harris, T.R., and Brigham, K.L. High-dose corticosteroids in patients with the adult respiratory distress syndrome. N. Engl. J. Med. 317,1565, 1987.

44. Bone, R.C., Fisher, C.J., Jr., Clemmer, T.P., Slotman, G.J., Metz, C.A., and the Methylprednisolone Severe Sepsis Study Group. Early methylprednisolone treatment for septic syndrome and the adult respiratory distress syndrome. Chest 92,1032, 1987.
45. Cochrane, C.G., Spragg, R., and Revak, S.D. Pathogenesis of the adult respiratory distress syndrome: Evidence of oxidant activity in bronchoalveolar lavage fluid. J. Clin. Invest. 71,754, 1983.

46. Baldwin, S.R., Simon, R.H., Grum, C.M., Ketai, L.H., Boxer, L.A., and Devall, L.J. Oxidant activity in expired breath of patients with adult respiratory distress syndrome. Lancet 1,11 , 1986. 